\title{
Endüstriyel Plantasyonlar Ve Orman Ürünleri Endüstrisi
}

\author{
Özden GÖRÜCÜ ${ }^{1}$, Ahmet TOLUNAY ${ }^{2 *}$, Yı1dız GÜNEŞ ${ }^{3}$, Pınar TOPÇU ${ }^{4}$ \\ ${ }^{1}$ Sütçü İmam Üniversitesi, Orman Fakültesi, Orman Mühendisliği Bölümü, 46100, KAHRAMANMARAȘ \\ ${ }^{2}$ Isparta Uygulamalı Bilimler Üniversitesi, Orman Fakültesi, Orman Mühendisliği Bölümü, 32200, ISPARTA \\ ${ }^{3}$ Sütçü İmam Üniversitesi, Fen Edebiyat Fakültesi, Coğrafya Bölümü, 46100, KAHRAMANMARAŞ \\ ${ }^{4}$ Ankara Üniversitesi, Ziraat Fakültesi, Toprak Bilimi ve Bitki Besleme Bölümü, 06110, ANKARA
}

Öz

Endüstriyel plantasyonlar, birçok ülkede ekonomik kalkınma ve büyüme parametreleri açısından önemli rol oynamaktadır. Türkiye'de orman ürünleri ve özellikle odun hammaddesi üretimi açısından arz açı̆̆ bulunmaktadır. Odun ürünleri bakımından ortaya çıkan arz açığının kapatılmasının en önemli yollarından biri endüstriyel plantasyonlara ağırlık vererek uygun alanlarda yaygınlaşmasını sağlamaktır. Bu makalede, küresel ölçekteki endüstriyel plantasyonlar ve orman ürünleri endüstrisi incelenerek, Türkiye için değerlendirmelerde bulunulmuştur.

Anahtar Kelimeler: Orman, Ormancılık, Ağaçlandırma. Odun ürünleri, Endüstriyel plantasyon, Türkiye.

\section{Industrial Plantations and Forest Products Industry}

\begin{abstract}
Industrial plantations play an important role in many countries in terms of economic development and growth parameters. In Turkey, there is a shortage of supply in terms of forest products and especially wood raw material production. One of the most important ways of closing the supply gap in terms of wood products is to make them widespread in suitable areas by giving weight to industrial plantations. This article is examining the industrial plantation and forest products industry on a global scale, there have been assessments for Turkey.
\end{abstract}

Keywords: Forest, Forestry, Afforestration, Wood products, Industrial plantations, Turkey. 


\section{Giriş}

Endüstriyel plantasyonlar olarak bilinen endüstriyel ağaçlandırmalar yuvarlak odun işleyen veya yuvarlak odunlardan elde edilen yarı mamul ürünleri hammadde olarak kullanan orman endüstrisine odun hammaddesi sağlayan ağaçlandırma çalışmalarıdır. Genellikle hızlı büyüyen iğne ve yapraklı ağaç türleri ile kurulan bu plantasyonlarda orman kurma, bakım ve üretim işleri, mekanizasyona dayalı entansif orman işletmeciliği gereklerine göre yapılmaktadır.

Orman amenajmanı ilkelerine göre yönetilen endüstriyel plantasyonlardan idare süresi sonunda elde edilen odun hammaddesi, dünya nüfusundaki artışa bağlı olarak her geçen gün artan ve çeşitlenen orman ve orman ürünleri talebinin karşılanmasına yönelik olarak kullanılmaktadır (FAO 2007). Dünyada endüstriyel plantasyonların alansal olarak artması ve hızla yaygınlaşmasının nedenleri arasında;

- Artan dünya nüfusunun odun temelli tüketim ihtiyaçlarının karşılanması,

- Azalan doğal ormanların korunması,

- Fosil yakıt fiyatlarının her geçen gün artması (Burschel 1995),

- Küresel ısınmanın artmasından dolayı yeşil biyoenerjinin daha çevre dostu olması ve yutak alan olarak ağaçlandırma sahalarının karbon emilimlerinin yüksek olması,

- Çölleşme ve erozyon tehdidinin giderek artması,

- Biyolojik çeşitliliğin korunması ve sürdürülebilirliği yer almaktadır.

Küresel ölçekte yuvarlak odun üretimi yıllık 3,4 milyar $\mathrm{m}^{3}$ civarında olup, bunun \%53'ü yakacak odun, \%47’si ise endüstriyel odundur. Yakacak odunun yaklaşı \% 090 'nı gelişmekte olan ülkeler tarafından üretilmekte iken, endüstriyel odunun \%79'u gelişmiş ülkeler tarafından üretilmektedir. Endüstriyel odun üretiminde belli başlı ülkeler sırasıyla Amerika Birleşik Devletleri (ABD), Kanada, Rusya Federasyonu, Brezilya ve Çin Halk Cumhuriyeti'dir (FAO 2007, FAO 2011).

Türkiye'de endüstriyel odun ihtiyacı 17-18 milyon $\mathrm{m}^{3}$ olup, bu ihtiyacın ancak \% 94'lük bölümü ülke içindeki kaynaklarımızdan karşılanmaktadır. Kalan arz açı̆̆ı ithalat yolu ile giderilmektedir. Ormancılık Ana Planı'nda, Türkiye'de kişi başına odun hammaddesi tüketim düzeyi 0,571 m³/kişi/yıl olarak verilmiştir. Ekonomik açıdan ileri ülkelerde, kişi başına odun hammaddesi tüketimi 1,0-1,5 m³/kişi/yıl düzeylerindedir. Bu nedenle Ormancılık Ana Planı'nda hızla artmakta olan odun hammaddesi talebini karşılayabilmek için Endüstriyel Plantasyon İşletmeciliğine önem verilerek odun üretiminin arttırılması hedeflenmiştir (OGM 2013).

Türkiye'de yılda 27-28 milyon $\mathrm{m}^{3} / \mathrm{y}$ l kadar odun hammaddesi tüketilmektedir. Orman alanlarının bugünkü üretim gücü ise 33,6 milyon $\mathrm{m}^{3}$ /yıl civarındadır. Bu miktarın 18-20 milyon m³/yıl kadarı Orman Genel Müdürlüğü (OGM) tarafından üretilmektedir. Ahşaba alternatif ikame maddelerin çevre için oluşturduğu olumsuzluklar karşısında son yıllarda ahşap kullanımına dönülmesi, odun hammaddesi talebinde önemli oranda artış olmuştur (OGM 2013).

Kâğıdın yapımında kullanılan başlıca odun hammaddesi; karaçam, kızılçam, sarıçam, göknar, kayın, kavak, ladin, okaliptüs gibi ağaçlar ile saman, kendir, keten, jüt kamışı gibi tarım bitkilerinden elde edilmektedir. Ayrıca, atık kâğıtlar, keten, kendir eskileri ve pamuklu paçavraların da hammadde olarak tarihsel seyir içerisinde kullanıldığı bilinmektedir. Kâğıt tüketiminde, birçok unsur etkili olmaktadır. Bunların başında "nüfus artışı" gelmektedir. Ülkelerin refah seviyesindeki yükseliş de kâğıt tüketimini artırmaktadır. Kâğıt; eğitim, sağlık, iletişim ve sanayi gibi birçok sektörde yoğun olarak kullanılmaktadır. Gelişen teknolojiyle birlikte endüstride üretilen malların birbirinin yerini alması da kâğıt tüketimini etkilemektedir.

Dünyanın güney bölgesindeki ülkelerde yoğun odun üretimi orman kaynakları için bir tehdit unsuru olmakla birlikte, bir diğer olumsuzluk selüloz üretimini hızlandırmak ve maliyetleri azaltmak için doğal ormanların yerine hızlı büyüyen ağaç türlerinin mono kültürlerini tesis etmektir. Endonezya'da olduğu gibi ABD, Şili, Avustralya ve Brezilya'da da doğal ormanlar plantasyon kurabilmek amacıyla büyük ölçüde tahrip edilmiştir. Birleşmiş Milletler Gıda ve Tarım Örgütü (FAO), tropik bölgelerde doğal orman alanlarının her yıl farklı amaçlar için yok edildiğini ve yeni kullanımın yaklaşı \% \%-7'sinin tohum ekimi ve fidan dikimi olduğunu tahmin etmektedir (FAO 2007, FAO 2011).

Küresel ölçekte en fazla biyolojik çeşitliliğe sahip ülkelerden biri olan Endonezya'da, doğal ormanlar sürekli olarak tek renkli alanlara dönüştürülmektedir. Yaklaşık yarısı eski doğal orman arazisinde olan 1,4 milyon hektarlık endüstriyel plantasyon alanı bulunmaktadır. Endonezya'da her yıl 2,8 milyon hektar doğal ormanın tahrip edildiği bilinmektedir. Şili'deki doğal orman kaybının başlıca nedeni, egzotik ormanların plantasyonlara 
dönüştürülmesidir ki bu ülkede 1978-1987 döneminde, kıyı bölgesindeki doğal ormanların \%31'i plantasyon oluşturmak için yok edilmiştir.

Brezilya'da da kâğıt hamuru şirketleri binlerce hektarlık doğal Atlantik yağmur ormanını temizleyerek bunları okaliptüs plantasyonlarına dönüştürmüştür. Başlangıçta, "Mata Atlântica (Atlantik Yağmur Ormanı)", Espírito Santo Eyaletinin çoğunu kapsarken, bugün sadece 10 milyon hektar kaldığı bilinmektedir.

Bu çalışmada, Dünya'da ve Türkiye'de endüstriyel plantasyonlar ve orman ürünleri endüstrisi incelenmek suretiyle aşağıdaki amaçlar hedeflenmiştir:

- Dünya'da ve Türkiye'de endüstriyel plantasyonlardaki gelişmeleri ortaya koyarak odun hammaddesi tedarikindeki yeri ve önemine bilimsel veriler ışığında vurgu yapmak,

- Endüstriyel plantasyonların ekolojik isteklerine göre uygun ağaç türleri üzerinde irdelemeler yaparak uygulamaya yol göstermek ve böylece saha aplikasyonu başarısında ihtiyaç duyulan büyük veri altlığının oluşumuna destek vermek,

- Endüstriyel odun üretimini endüstriyel amaçlı kurulmuş plantasyonlara yönlendirerek, doğal ormanların korunması ve sürdürülebilirliğini sağlamak,

• Orman ürünleri sektörünün ihtiyaç duyduğu odun hammaddesi talebinin sürdürülebilir orman yönetimi prensiplerine göre sağlanmasına analitik veriler ışı̆̆ında destek vermektir.

\section{Materyal ve Metot}

\subsection{Materyal}

Dünya'da endüstriyel plantasyonlar, endüstriyel plantasyonlarda kullanılan ağaç türleri, odun ve odun türevli orman ürünlerinin endüstriyel kullanım alanları, Türkiye'de endüstriyel odun üretimi ve kullanım alanları ve Türkiye'nin odun ve odun türevi ürünler açısından durumu ile ilgili veriler Dünya Bankası (World Bank), Birleşmiş Milletler Gıda ve Tarım Teşkilat (United Nations Food and Agriculture Organization, UN-FAO), Orman Genel Müdürlüğü (OGM), Türkiye Odalar ve Borsalar Birliği (TOBB) Orman Ürünleri Sektörü, Uluslararası Ticaret Merkezi (International Trade Center-ITC), Türkiye İstatistik Kurumu (TÜIKK) gibi kurum ve kuruluşlardan temin edilmiştir.

\subsection{Metot}

Çalışma asli olarak veri analizine dayanmaktadır. Veri, anlam kazanmamış, ilişkilendirilmemiş, özümlenmemiş, işlenmemiş gerçekler ya da bilgi parçacıklarıdır. Herhangi bir içerikten yoksun formlardadırlar. Bazen fiziksel bir olaydır, yorumlanmamış gözlemlerdir. Yorum taşımazlar ancak işlenmek için hazırdırlar. Karar vermede etkili değillerdir.(Karakuş 2018).

Ulusal ve uluslararası düzeydeki çeşitli kurum ve kuruluşlardan toplanan veriler enformasyon işlemi ile bilgiye dönüştürülmüştür. Enformasyon sözcügü, İngilizce'deki “information” sözcüğünün Türkçe'ye uyarlanmış halidir. Enformasyon, veriye değer katılarak, verinin anlamlandırılmasıdır. Belli bir amaç için birbiriyle ilişkili verilerin bir araya getirilmesi, düzenlenmesi sonucu oluşur ve bir anlam taşımaktadır.

Verilerin enformasyona dönüştürme işleminde; verilerin toplanma amaçları belirlenmekte, bu amaçlara göre veriler sınıflandırmakta, ilişkili olmayan veriler ayıklanarak hatalar düzeltilmekte, eksik veriler kestirimsel olarak yerine konulmakta, veriler analiz edilerek birbirleriyle olan ilişkileri belirlenmekte, matematiksel modeller ile algoritmalar oluşturulmakta, belirsizlikler, değişimler, sapmalar ortaya konulması ile kullanışlı bilimsel bilgiye ulaşılmaktadır. Genel olarak bilgi, veri ve enformasyonun yorumlanmasıyla ortaya çıkmaktadır. Verinin bilgiye dönüşme süreci: "Toplama", "Sınıflandırma", "Düzenleme", "Özetleme", "Saklama", "Yeniden elde etme" ve "İletme" aşamalarından oluşmaktadır. Bu çalışmada verinin bilgiye dönüşme sürecinin tüm aşamaları kullanılmıştır (Karakuş 2018).

\section{Bulgular ve Tartışma}

\subsection{Dünyada Endüstriyel Plantasyonlar}

Kıtalara göre endüstriyel plantasyonların dağılımı Şekil 1'de verilmiştir. FAO’nun 2007 ve 2011 yılı verilerine 
göre, \%62 oranı ile dünyada birinci sırayı Asya kıtasının aldığı görülmektedir. Asya kıtasında endüstriyel plantasyonların bu kadar büyük oranda bulunmasının nedenleri olarak toprak genişliği ve uygun iklim koşullarının etkisi vardır. İkinci sırayı ise \%17 oranı ile Avrupa kıtası almaktadır. Avrupa kıtasında endüstriyel amaçlı plantasyonların gelişmesindeki en önemli nedenler, ülkelerin ihtiyacı olan orman ve orman ürünlerini karşılayarak dışa bağımlılıktan kurtulmak ve ayrıca ihtiyaç duyulan temiz ve sürdürülebilir enerjinin doğaya ve doğal ekosistemlere en az zarar veren biyoenerjiden karşılamaktır (Rüter, 2013). Üçüncü sırayı ise toplamda \%15'lik pay ile Amerika kıtası (Kuzey Amerika; \%9 ve Güney Amerika; \%6) takip etmektedir.

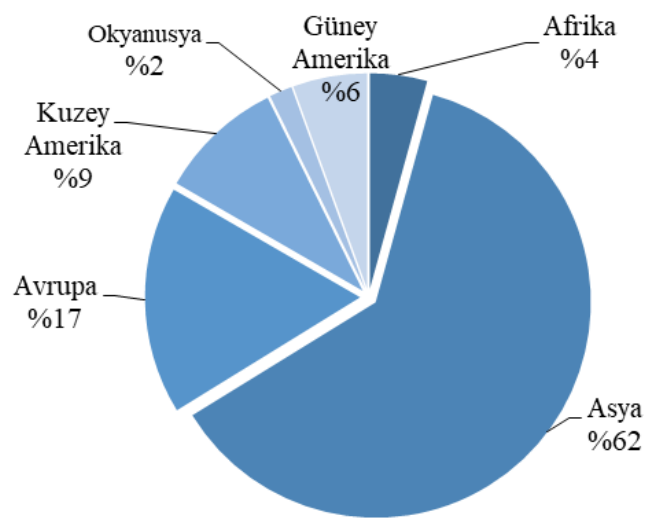

Şekil 1. Endüstriyel plantasyonların kıtalara göre dağılımı (FAO 2007, 2011).

Endüstriyel plantasyon alanı genişliği bakımından ülkelerin durumu Şekil 2'de belirtilmiştir. Şekil 2 incelendiğinde; Asya kıtasının son yıllarda en hızlı büyüyen ekonomisine sahip Çin’in birinci sırada geldiği görülmektedir.

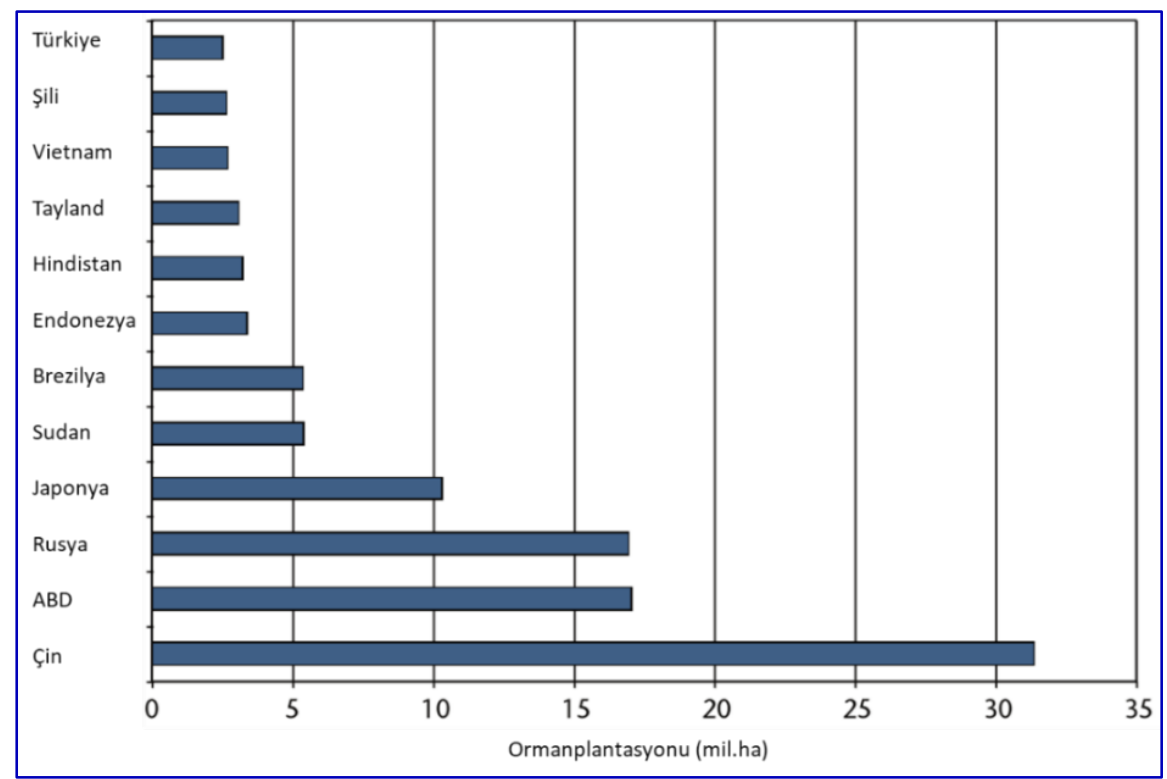

Şekil 2. Ülkelerin sahip olduğu endüstriyel plantasyon alanları (FAO 2007).

Son yıllarda dünyanın en hızlı büyüyen ekonomileri arasında bulunan Çin 31,5 milyon hektar endüstriyel plantasyon alanına sahip bir ülkedir. Çin, özellikle son yıllarda artan nüfusunun yapacak ve yakacak odun ihtiyacını karşılamak ve doğal ormanlarını daha etkin korumak amacıyla yoğun bir şekilde endüstriyel plantasyon alanlarını genişletme yoluna gitmiştir. Bunun bir sonucu olarak bu ülkede, orman ürünleri ihracat oranlarının da giderek artan bir eğilim sergilemektedir.

Çin’de ormancılık sektörünün giderek büyümesinin nedenleri arasında, isabetli ormancılık politikalarının 
belirlenmesi ve bu politikalara uygun orman ekosistemlerinin varlığı ve doğal kaynakların sürdürülebilir yönetilmesi bulunmaktadır. Endüstriyel plantasyon alanı büyüklüğü bakımından Çin’den sonra ABD ve Rusya gelmektedir.

Ülkelerin odun ve odun türevli dış ticareti Şekil 3'te verilmektedir. Şekil 3'e göre en fazla ihracatı 70 milyar ABD Doları ile ABD'nin gerçekleştirdiği, ikinci sırayı 50 milyar ABD doları ile Çin'in, üçüncülüğü ise 40 milyar ABD Doları ile Almanya almaktadır (Messina, 2012).

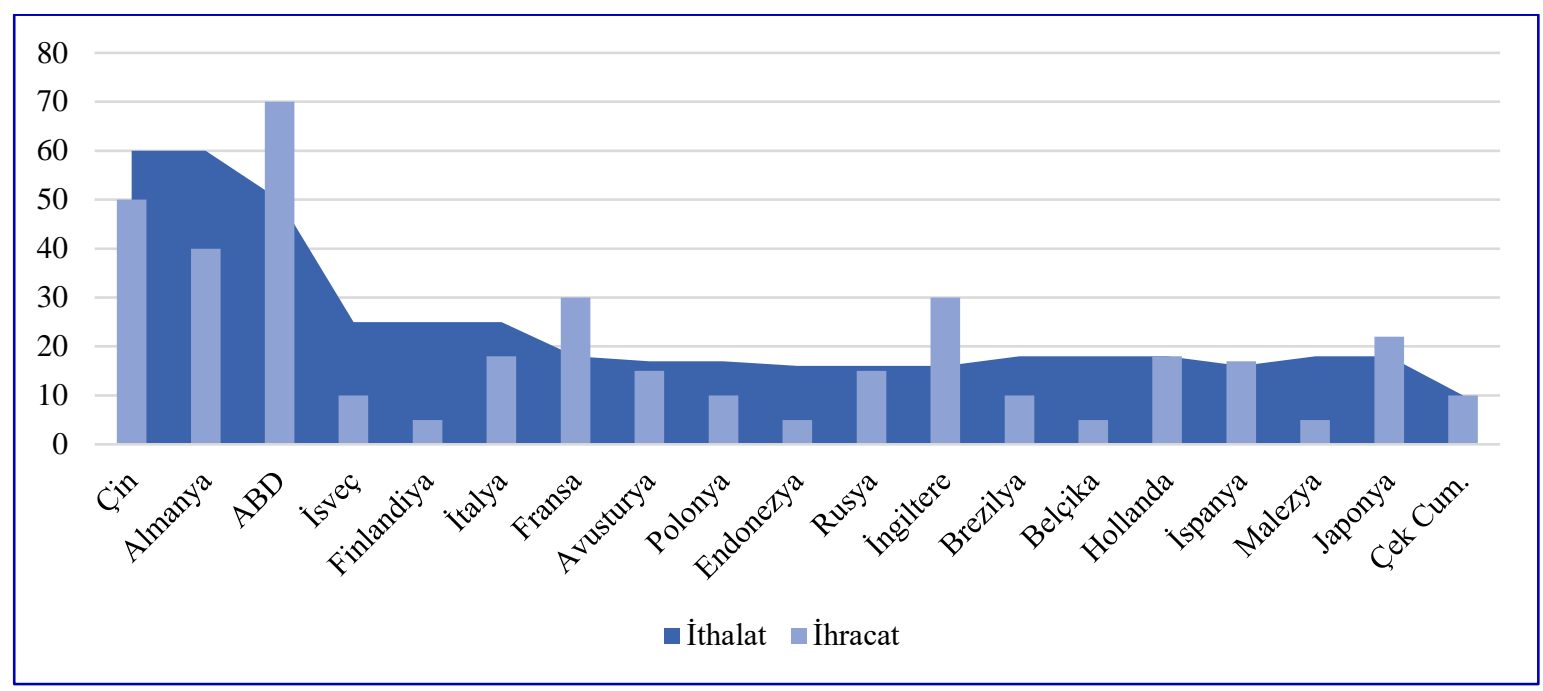

Şekil 3. Ülkelerin odun ve odun türevli dış ticareti (URL1 2012).

Nüfus artışına paralel olarak, Dünya genelinde orman ürünlerine olan talebin de artığı gözlenmektedir (World Bank, 2011; FAO, 2011). Çünkü, küresel ölçekte biriken sermaye ve tasarruf hacminin birçok yatırım mekanizmasına yönlendiği bilinmektedir. Bu kapsamda, son yıllarda bir kısım sermayenin orman kaynakları ve ormancılık sektörüne doğru yön kazandığı görülmektedir. Bu gelişmenin temelinde ülkelerin kalkınma ve büyüme mekanizmalarının odağına yeşil ekonomik parametreleri ve buna bağlı stratejik eylem planlarını almaları gösterilebilir. Zira, Binyıl Kalkınma Hedefleri çevresel sürdürülebilirlik temelinde "doğa dostu kalkınma" ve "büyüme modellerini" esas almaktadır.

\subsection{Türkiye'nin Odun ve Odun Türevi Ürünler Açısından Durumu}

Odun ve odun türevi ürünler cinsinden Türkiye'nin ithalat ve ihracat verileri Şekil 4'te verilmektedir. Şekil 4'ten Türkiye'nin yonga levha, kereste ve endüstriyel odun ile kontrplak ithalatının oldukça yüksek olduğu; bununla birlikte, lif levha ve işlenmiş ürün ihracatının da oldukça iyi düzeylerde olduğu görülmektedir.

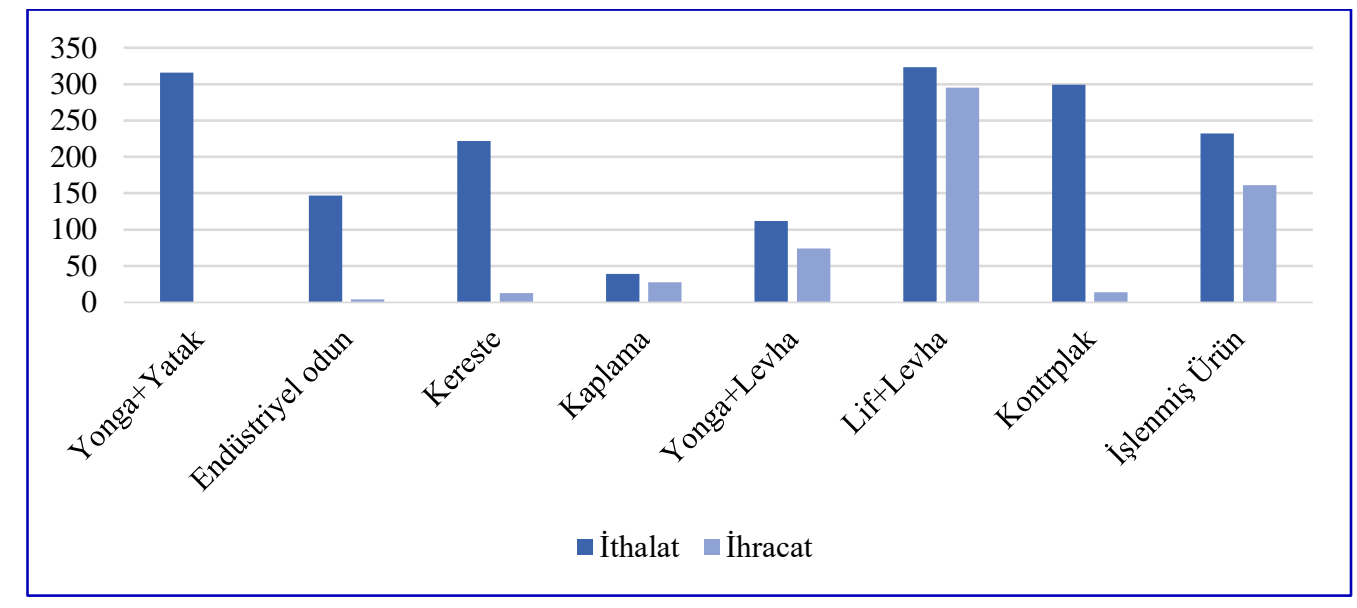

Şekil 4. Türkiye'nin odun ve odun türevi ürünler ithalat ve ihracatı (2013). 
Türkiye'de orman ürünleri sektörünün hammadde ihtiyacını karşılamak üzere piyasaya sunulan endüstriyel ve yakacak odun miktarları Tablo 1'de verilmiştir.

Tablo 1. Türkiye'de endüstriyel ve yakacak odun arzı.

\begin{tabular}{|c|c|c|}
\hline Arz Kaynağı & $\begin{array}{l}\text { Endüstriyel Odun } \\
\left(\text { (bin } \mathbf{m}^{3}\right)\end{array}$ & $\begin{array}{l}\text { Yakacak Odun } \\
\left(\text { bin } \mathbf{m}^{3}\right)\end{array}$ \\
\hline OGM Üretimi & 13.712 & 4.746 \\
\hline İthalat & 837 & 172 \\
\hline Özel Sektör Üretimi & 3.300 & 1.570 \\
\hline Kayıt Dışı Üretim & - & 3.375 \\
\hline Toplam & 17.846 & 9.863 \\
\hline
\end{tabular}

Kaynak: URL2 2013.

Tablo 1'de yer alan verilere göre, toplam 17.846.000 $\mathrm{m}^{3}$ olan endüstriyel odun arzının $13.712 .000 \mathrm{~m}^{3}$ 'ü OGM tarafindan piyasaya sunulurken, $837.000 \mathrm{~m}^{3}$ ’ü ithalat yoluyla ülkeye girmektedir. Özel sektörün endüstriyel odun üretimi ise 3.300.000 $\mathrm{m}^{3}$ düzeyindedir. Buna göre Türkiye'de odun üretimi bakımından halen monopol ve tek tedarikçi konumunda bulunan OGM, ülkede sunulan odun hammaddesinin çok büyük bir kısmını sağlamaktadır. Yakacak odunun ise $4.746 .000 \mathrm{~m}^{3}$ 'ü OGM üretimiyle elde edilirken, $3.375 .000 \mathrm{~m}^{3}$ 'ü kayııt diş1 yollarla elde edilmekte ve bununla birlikte $1.570 .000 \mathrm{~m}^{3}$ '̈̈ ise özel sektör tarafindan üretilerek piyasaya sunulmaktadır.

\subsection{Dünya'da ve Türkiye'de Endüstriyel Plantasyonlarda Kullanılan Ağaç Türleri}

Dünya'da endüstriyel plantasyonlarda yaygın olarak kullanılan ağaç türleri Şekil 5'te gösterilmektedir. Dünya genelinde endüstriyel plantasyonlar da önceliğin yerli türlere verildiği görülmektedir. Bunun sebebi olarak; biyolojik, ekolojik ve ekonomik avantajları söylenebilir.

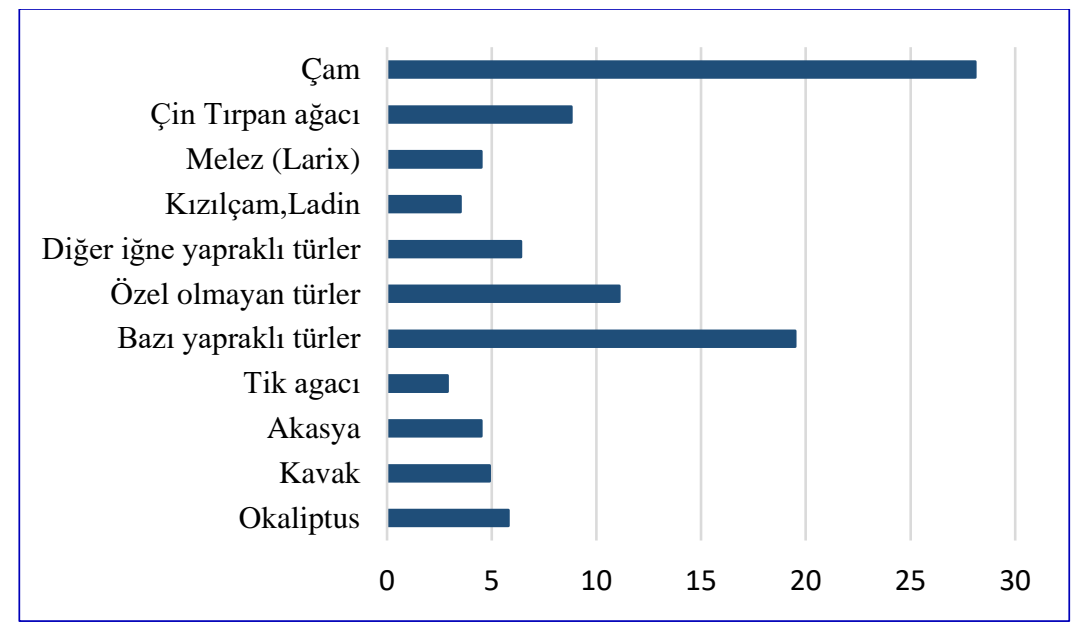

Şekil 5. Dünyada endüstriyel plantasyonlarda yaygın olarak kullanılan ağaç türleri (FAO 2007).

Yeni Zelanda'da 1,85 milyon hektar ve Avustralya'da 1,77 milyon hektar alanda iğne yapraklı ağaçlardan çam türleri ile dünyanın en geniş endüstriyel plantasyon sahaları tesis edilmiştir. Dünya genelinde alan itibariyle yaklaşık \%30'luk bir plantasyon payına sahip olan çam türleri şimdiye kadar en çok kullanılan ağaç türleri olarak dikkat çekmektedir (FAO 2007; Bemmann vd., 2008).

İsviçre'de tesis edilen endüstriyel plantasyonların yaklaşık \%51,4’ünde her dem yeşil türler kullanılırken, \%37,5'inin yaprak döken ağaçlardan ve \% 11,1'inin ise diğer türlerden oluştuğu görülmektedir. Çin'de plantasyon sahalarında \%5,8 ile en fazla okaliptüs türü kullanılırken, ikinci sırada \%4,9 ile kavak türünün kullanıldığ görülmektedir, bunların dışında yerli tür olan Castanopsis hystrix ve Michelia macclurei'nin kullanıldığı da bilinmektedir. Tüm Asya’da olmak üzere özellikle Çin'de artan nüfusun odun ihtiyacını karşılamak maksadıyla 
en fazla okaliptus ve çam ağacı plantasyonlarına ağırlık verilmektedir. Brezilya özellikle son 30 yılda selüloz üretimine yönelik odun ve odun türevli ürünlerde verimli üretim yapabilmeyi başarmıştır, bu kapsamda okaliptus ormanlarından ortalama 20-40 $\mathrm{m}^{3}$ /hektar üretim ile kendi kereste ihtiyacının \%63'ünü karşılamaktadır (FAO 2007; Bemmann vd., 2008).

Dünya'da endüstriyel plantasyonlarda kullanılan en önemli türlerden olan Populus nigra ve Populus maximowiezii türlerinin Avrupa'da uzun yıllardan beri orman endüstrisi ve enerji üretimi amaçlı olarak kullanıldığı görülmektedir. Son yıllarda yürütülen araştırmalardan elde edilen sonuçlara göre, Dünyada en hızlı büyüyen ağaç türü olarak tespit edilen Paulownia türünün birçok ülkenin dikkatini çektiği ve araştırmaların bu türün ekolojik ve botaniksel özellikleri ile çap ve hacim artımı üzerine yoğunlaştığı bilinmektedir (Stimm vd. 2013; URL3 2014).

Bununla birlikte, Kuzeydoğu Avrupa'da kısa idare süreli plantasyonlarda taban suyunun yüksek olduğu sahalarda hızlı büyüdüğü bilinen söğüt türü tercih edilmekle birlikte, özellikle daha kurak iklim özellikleri görülen güneydoğu Avrupa'da ise akasya türünün kullanıldığı görülmektedir (Weisgerber 2004).

Türkiye'de ise endüstriyel plantasyonda yaygın olarak kızılçam, sahilçamı, okaliptüs, dişbudak, kavak kullanılmakta olup, bu ağaç türlerine ilişkin bilgi Tablo 2'de verilmiştir.

Tablo 2. Türkiye’de endüstriyel plantasyonlarda yaygın olarak kullanılan ağaç türleri.

\begin{tabular}{llr}
\hline No & A ğaç Türü & Alan (hektar) \\
\hline $\mathbf{1}$ & Kizılçam & 145.151 \\
$\mathbf{2}$ & Sahilçamı & 14.069 \\
$\mathbf{3}$ & Dişbudak & 3.393 \\
$\mathbf{4}$ & Okaliptus & 1.190 \\
$\mathbf{5}$ & Kavak & 1.119 \\
& Toplam & $\mathbf{1 6 4 . 9 2 2}$ \\
\hline
\end{tabular}

Kaynak: OGM, 2013.

1981 yılına kadar özel sektör ağaçlandırmaları dâhil olmak üzere, “kavak” ve “okaliptüs” gibi hızlı gelişen türlerle yapılan ağaçlandırmanın toplam alanı 80.000 hektar civarındadır. Türkiye’de giderek artan endüstriyel odun talebinin OGM’yi yeniden hızlı gelişen türlerle endüstriyel ağaçlandırma uygulamaları yapmaya yöneltmiştir. Bunun neticesinde, 2013-2017 dönemi OGM Stratejik Planı'nda her yıl 10.000 hektar alanda hızlı gelişen türlerle ağaçlandırma yapılmasının planlandığı ve bu hedefe ulaşmak üzere çalışmaların yoğunlaştığı görülmektedir (OGM 2013).

\subsection{Dünyada Odun ve Odun Türevli Orman Ürünlerinin Endüstriyel Kullanım Alanları}

Orman ve orman ürünleri dünyanın pek çok ülkesinde farklı alanlarda kullanılmakta ve ekonomik göstergelere (büyüme, istihdam, gayrisafi milli hasıla gibi) önemli katkı sağlamaktadır. Orman ve orman ürünleri hammadde, ara malı veya nihai mal olarak kullanılmaktadır. Farklı şekillerde kullanılan bu ürünlerin, doğal ve organik olması sağlık açısından önem arz ettiği gibi aynı zamanda yetiştirme ve üretim maliyetlerinin düşük olması nedeniyle ekonomik açıdan tercih edilen ürünlerdir (FAO 2011).

Biyoenerji, canlı organizmalar ya da bunların metabolik yan ürünlerinden elde edilen bir enerji türüdür. Biyoyakıtlar biyolojik esaslı bir maddeden ya da biyokütleden elde edilen yakıtlardır. Biyoenerjinin üretildiği çok çeşitli biyolojik kaynakların bütününe genel anlamda "biyokütle" denilmektedir. Bu enerji kaynağını kömür, petrol, nükleer gibi diğer tabii kaynaklardan ayıran temel fark biyokütlenin yenilenebilir bir enerji kaynağ olmasidır (URL4 2018).

Odunsu biyokütle yakıtının fosil yakıtlara göre bazı üstünlükleri bulunmaktadır. Odun yenilenebilir bir kaynaktır. Diğer bir üstünlüğü, yandığı zaman fosil yakıtlara göre \%90 daha az $\mathrm{CO}_{2}$ çıkarmaktadır. Fosil yakıtlara göre çevre dostu ayrıca çok az asit yağmuru ve duman üretmektedir. Odun içinde sülfür ve ağır metal oranı çok düşüktür. Uygun teknolojiler ve uygun yöntemler kullanılarak doğru bir şekilde enerjiye dönüştürüldüğünde, çevre üzerinde zararı az, hızlı bir şekilde yeniden üretilebilen, uzun süreli ve güvenli bir enerji kaynağıdır. Biyokütleden sadece yakılarak enerji üretilmemekte, aynı zamanda gazlaştırma, piroliz, fermantasyon gibi yöntemlerle gaz veya sıvı başka yakıtlara dönüştürülerek enerji de üretilebilmektedir. 
Dünyada odun ve odun türevli orman ürünlerinin endüstriyel kullanım alanlarına ilişkin belli başlı sektörler Şekil 6'da verilmiştir.

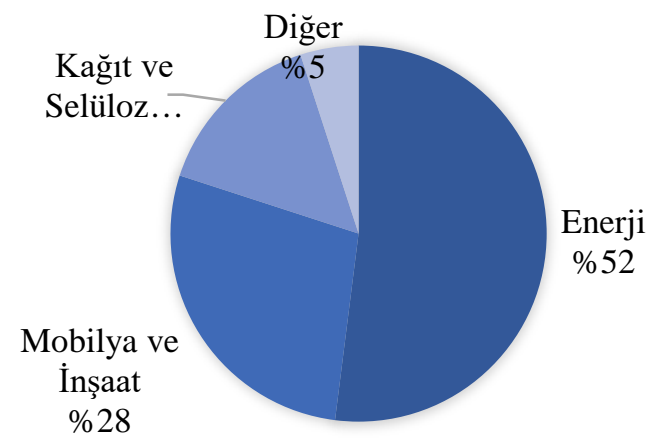

Şekil 6. Dünyada odun ve odun türevli orman ürünlerinin kullanıldığı sektörler (Finnish Forest Industries Federation, 2007).

Şekil 6'ya göre, \%52'lik payla enerji amaçlı kullanımın birinci sırada yer aldığını, ikinci sırada ise \%28'lik payla mobilya ve inşaat sektörünün olduğu görülmektedir. Kâğıt ve selüloz amaçlı kullanımının ise \%15'lik paya sahip olduğu ve en düşük payın ise endüstriyel amaçlı diğer kullanımlar olduğu anlaşılmaktadır.

\subsection{Kâğıt ve Karton Sektörü}

FAO/UNECE verilerine göre, 2015 yılında dünya genelinde kâğıt ve kâğıt ürünleri üretimi 406.295 bin ton olarak gerçekleşmiştir. Bu üretimi karşılayan ilk beş ülke ise sırasıyla; Çin (111.150 ton), ABD (72.397 ton), Japonya (26.228 ton), Almanya (22.602 ton) ve Hindistan (14.961 ton) yer almaktadır. Yıllar itibarıyla dünya kâğıt ve karton üretim ve tüketim verilerine Şekil 7'de yer verilmektedir.

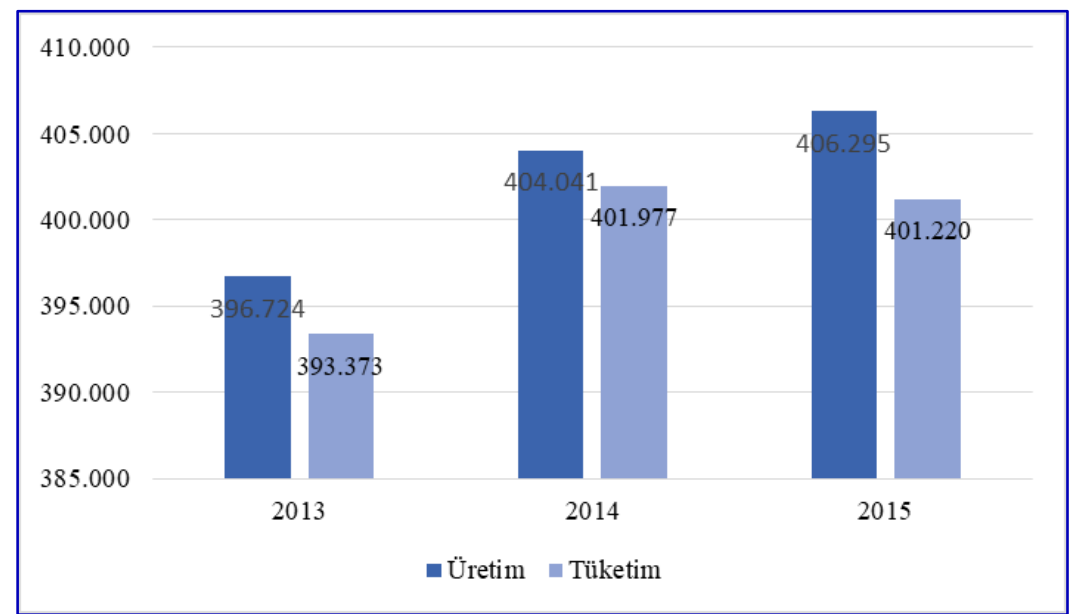

Şekil 7. Dünya kâğıt ve karton üretimi ve tüketimi (URL5 2018).

Kâğıt ve karton üretimi sektöründe; toplam üretimin yarıdan fazlasını ambalaj ve etiket kâğıdı oluşturmaktadır. Ürün bazında değerlendirildiğinde ise ambalaj ve etiket kâğıdı ile temizlik kâğıdı ürünlerinin sektördeki payının artması beklenmektedir. Teknolojik gelişmelerle birlikte, dijitalleşmenin hızlandığı günümüzde yazı ve baskı kâğıdı ile gazete kâğıdı üretiminin ise gerileyeceği tahmin edilmektedir.

Kâğıt sektöründe bir ara ürün olan selülozun 2017 yılı ITC verilerine göre dünya ithalat1 55.504.601 bin ABD Dolarıdır. Bu kapsamda, selüloz ithalatçısı başlıca ülkeler arasında Çin (21.211.288 bin ABD Doları), Almanya (4.477.961 bin ABD Doları) ve ABD (3.301.960 bin ABD Doları) yer almaktadır. Yine, 2017 yılı ITC verilerine göre, selüloz hammaddesinin dünya ihracat rakamı 47.865.425 bin ABD Dolarıdır. Başlıca selüloz ihracatçısı ülkeler ise ABD (8.916.250 bin ABD Doları), Kanada (6.382.917 bin ABD Doları) ve Brezilya (6.355.349 bin 
ABD Doları)'dır. Türkiye; selüloz ithalatında dünya sıralamasında 12. sırada (949.949 bin ABD Doları), ihracatında ise 54. sırada (21.826 bin ABD Doları) yer almaktadır. Dünya kâğıt ve karton ithalatına ilişkin bilgiler Tablo 3'te bulunmaktadır.

Tablo 3. Dünya kâğıt ve karton ithalatı (bin ABD Doları).

\begin{tabular}{lllll}
\hline No & İthalatçı Ülkeler & $\begin{array}{l}\mathbf{2 0 1 5} \\
\text { (bin \$) }\end{array}$ & $\begin{array}{l}\mathbf{2 0 1 6} \text { ( } \\
\text { bin \$) }\end{array}$ & $\begin{array}{l}\mathbf{2 0 1 7} \\
\text { (bin \$) }\end{array}$ \\
\hline $\mathbf{1}$ & ABD & 16.676 .532 & 16.448 .007 & 16.418 .754 \\
$\mathbf{2}$ & Almanya & 13.339 .149 & 13.399 .314 & 14.039 .086 \\
$\mathbf{3}$ & Fransa & 7.793 .320 & 7.802 .773 & 8.111 .841 \\
$\mathbf{4}$ & İngiltere & 8.212 .681 & 7.375 .625 & 7.218 .451 \\
$\mathbf{5}$ & İtalya & 5.101 .861 & 5.079 .789 & 5.593 .768 \\
& Dünya & 157.898 .573 & 156.108 .289 & 163.633 .352 \\
\hline
\end{tabular}

Kaynak:URL6 2018.

Dünya kâğıt ve kartonun ihracatına ilişkin bilgiler ise Tablo 4’te yer almaktadır.

Tablo 4. Dünya kâğıt ve karton ihracatı (bin ABD Doları).

\begin{tabular}{lllll}
\hline No & İhracatçı Ülkeler & $\begin{array}{l}\mathbf{2 0 1 5} \\
\text { (bin \$) }\end{array}$ & $\begin{array}{l}\mathbf{2 0 1 6} \\
\text { (bin \$) }\end{array}$ & $\begin{array}{l}\mathbf{2 0 1 7} \\
\text { (bin \$) }\end{array}$ \\
\hline $\mathbf{1}$ & Almanya & 19.083 .833 & 19.321 .801 & 20.278 .225 \\
$\mathbf{2}$ & Çin & 18.752 .436 & 17.610 .116 & 18.417 .668 \\
$\mathbf{3}$ & ABD & 15.697 .909 & 14.866 .366 & 15.762 .815 \\
$\mathbf{4}$ & İsveç & 8.411 .152 & 8.261 .830 & 8.575 .319 \\
$\mathbf{5}$ & Finlandiya & 8.061 .651 & 7.760 .018 & 8.030 .124 \\
& Dünya & 156.587 .023 & 153.528 .816 & 161.655 .997 \\
\hline
\end{tabular}

Kaynak: URL6 2018.

Türkiye, ithalatta dünya sıralamasında 15.sırada (2.811.914 bin ABD Doları) yer almaktadır (Tablo 5). 2017 yılı verilerine göre, Türkiye'nin ithalatta bulunduğu ilk üç ülke ise sırasıyla Almanya (2.811.914 bin ABD Doları), Finlandiya (443.535 bin ABD Dolar1) ve Çin (281.602 bin ABD Dolar1)'dir.

Tablo 5. Türkiye'nin kâğıt ve karton sektöründeki ithalatı (bin ABD Doları).

\begin{tabular}{|c|c|c|c|c|c|}
\hline No & Kâğıt-Karton Sektörü & $\begin{array}{l}2014 \\
\text { (bin \$) }\end{array}$ & $\begin{array}{l}2015 \\
\text { (bin \$) }\end{array}$ & $\begin{array}{l}2016 \\
\text { (bin \$) }\end{array}$ & $\begin{array}{l}2017 \\
\text { (bin \$) }\end{array}$ \\
\hline 1 & $\begin{array}{l}\text { Bir veya iki yüzü kaolin (porselen kili) veya diğer inorganik } \\
\text { maddeler ile sıvanmış kâğıt veya kartonlar }\end{array}$ & 777.643 & 622.262 & 618.048 & 715.827 \\
\hline 2 & Sıvanmamış kâğıt ve karton & 500.338 & 510.765 & 685.819 & 626.187 \\
\hline 3 & Birincil elyaf (kraft) kâğıt ve kartonlar & 420.801 & 344.183 & 321.218 & 356.249 \\
\hline 4 & Kâğıt, karton, selüloz vatka ve liften tabakalar & 384.448 & 342.314 & 332.813 & 382.856 \\
\hline 5 & Diğer kâğıt ve kartonlar & 279.278 & 209.026 & 204.214 & 236.116 \\
\hline 6 & Gazete kâğ $d_{1}$ & 243.789 & 172.708 & 131.627 & 112.524 \\
\hline 7 & Duvar kâğıtları ve benzeri duvar kaplamaları & 84.607 & 76.084 & 17.571 & 16.270 \\
\hline 8 & Diğer kâğıt, karton, selüloz vatka ve lif tabakaları & 82.773 & 67.386 & 59.964 & 52.161 \\
\hline 9 & Sigara kâğıdı & 67.117 & 61.612 & 63.879 & 68.855 \\
\hline 10 & Ambalaj kutuları & 65.923 & 58.327 & 59.796 & 50.818 \\
\hline 11 & Karbon kâğıdı, kendinden kopya eden kâğıt & 51.738 & 44.415 & 34.416 & 36.424 \\
\hline 12 & Bitkisel parşömen, yağ geçirmez ve çizim kâğıtları & 31.994 & 30.905 & 29.356 & 33.438 \\
\hline 13 & $\begin{array}{l}\text { Tuvalet kâğıtları ve ev işlerinde veya sağllk amaciyla kullanılan } \\
\text { türden benzeri kâğıt, selüloz vatka veya liflerden tabakalar }\end{array}$ & 18.065 & 10.667 & 5.953 & 5.020 \\
\hline 14 & Yapıştırma suretiyle elde edilen kâğıt ve kartonlar & 13.358 & 12.124 & 10.179 & 13.850 \\
\hline 15 & Oluklu kâğıt ve kartonlar & 8.792 & 5.665 & 5.315 & 7.288 \\
\hline 16 & Kâğıt hamurundan filtre edici blok ve levhalar & 2.640 & 1.715 & 1.475 & 2.265 \\
\hline \multirow[t]{2}{*}{17} & Diğger & 137.414 & 113.786 & 103.071 & 95.766 \\
\hline & Toplam & 3.170 .718 & 2.683.944 & 2.684.714 & 2.811.914 \\
\hline
\end{tabular}

Kaynak: URL7 2018. 
Türkiye, kâğıt ve karton ihracatında 25. sırada (1.521.008 bin ABD Doları) bulunmaktadır (Tablo 6). 2017 yılı verilerine göre, ihracat yaptığı ilk üç ülke ise İngiltere (1.521.008 bin ABD Doları), Irak (178.518 bin ABD Doları) ve İ̀srail (123.826 bin ABD Doları)'dir.

Tablo 6. Türkiye'nin kâğıt ve karton sektöründeki ihracatı (bin ABD Doları).

\begin{tabular}{|c|c|c|c|c|c|}
\hline No & Kâğıt-Karton Sektörü & $\begin{array}{l}2014 \\
(b i n \$)\end{array}$ & $\begin{array}{l}2015 \\
(\text { bin } \$)\end{array}$ & $\begin{array}{l}2016 \\
(\text { bin } \$)\end{array}$ & $\begin{array}{l}2017 \\
(\text { bin } \$)\end{array}$ \\
\hline 1 & Ambalaj kutuları & 365.740 & 335.266 & 395.913 & 471.129 \\
\hline 2 & $\begin{array}{l}\text { Tuvalet ve yüz temizliği için ince kâğıt, havlu veya kâğıt } \\
\text { peçete }\end{array}$ & 194.957 & 190.046 & 264.789 & 314.265 \\
\hline 3 & Kâğıt, karton, selüloz vatka ve liften tabakalar & 212.986 & 218.823 & 239.135 & 208.013 \\
\hline 4 & Diğer kâğıt ve kartonlar & 53.663 & 97.859 & 112.611 & 164.947 \\
\hline 5 & $\begin{array}{l}\text { Tuvalet kâğıtları ve ev işlerinde veya sağlık amacıyla } \\
\text { kullanılan türden benzeri kâğıt, selüloz vatka veya liflerden } \\
\text { tabakalar }\end{array}$ & 101.760 & 101.572 & 98.382 & 98.655 \\
\hline 6 & Diğer kâğıt, karton, selüloz vatka ve lif tabakaları & 58.535 & 47.465 & 47.142 & 54.808 \\
\hline 7 & Kâğıt veya kartondan her cins etiketler & 56.845 & 53.552 & 52.988 & 52.670 \\
\hline 8 & $\begin{array}{l}\text { Porselen kili veya diğer inorganik maddeler ile sıvanmış kâğıt } \\
\text { veya kartonlar }\end{array}$ & 36.018 & 43.529 & 34.933 & 38.740 \\
\hline 9 & $\begin{array}{l}\text { Kâğgt veya kartondan kayıt defterleri, hesap defterleri, sipariş } \\
\text { defterleri }\end{array}$ & 33.927 & 23.209 & 23.920 & 27.674 \\
\hline 10 & Sivanmamış kâğıt ve karton & 16.138 & 14.750 & 18.784 & 19.092 \\
\hline 11 & Duvar kâğıtları ve benzeri duvar kaplamaları & 15.923 & 7.556 & 4.758 & 9.580 \\
\hline 12 & Sigara kâğ ${ }_{1}{ }_{1}$ & 2.790 & 1.407 & 1.482 & 1.506 \\
\hline 13 & Gazete kâğ $\mathrm{d}_{1}$ & 791 & 667 & 510 & 670 \\
\hline \multirow[t]{2}{*}{14} & Diğer & 53.651 & 49.823 & 58.152 & 59.259 \\
\hline & Toplam & 1.203 .724 & 1.185 .524 & 1.353 .499 & 1.521 .008 \\
\hline
\end{tabular}

Kaynak: URL6 2018.

\subsection{Orman ve Orman Ürünlerinin Kullanıldığı Diğer Sektörler}

Dünyada orman ve orman ürünlerinden faydalanma alanında en fazla kullanımın $\% 52$ 'lik payla enerji üretimi alanında olduğu görülmektedir. Özellikle son 30 yılda fosil yakıt tüketiminin büyük oranda arttığı gözlenmiştir (Burschel, 1995). Önümüzdeki yıllarda fosil yakıt rezervlerinin azalmasına bağlı olarak fosil yakıt fiyatlarındaki artış ve enerjiye olan ihtiyacın artması söz konusu olacağından, enerji ihtiyacının yenilenebilir enerji kaynaklarından (güneş, rüzgâr gibi) karşılanmasına büyük ağırlık verileceği beklenmektedir (Burschel 1995). Enerji alanındaki tüm araştırmaların ve yatırımların da bu doğrultuda olduğu görülmektedir.
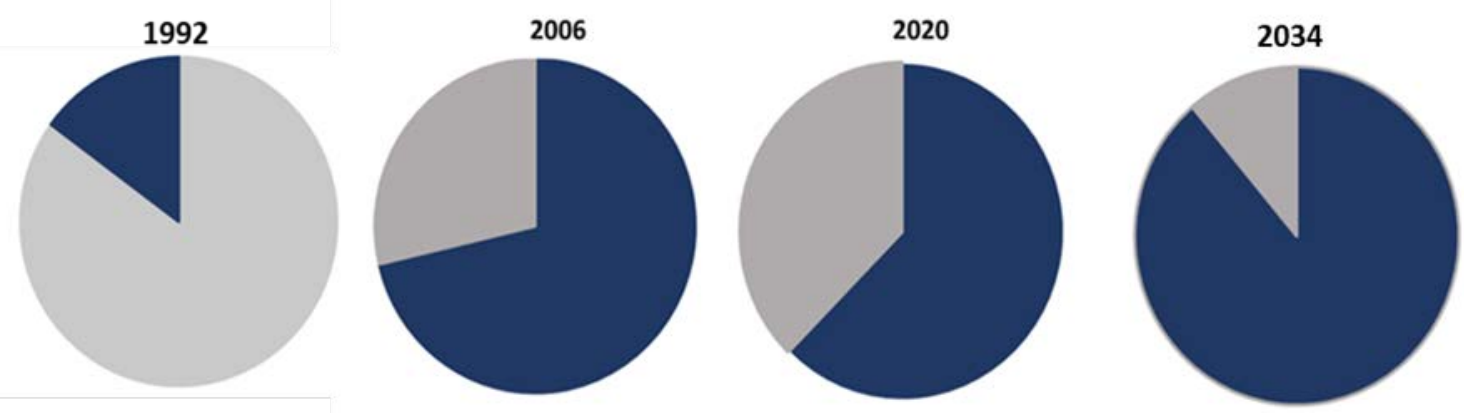

Şekil 8. Yıllara göre fosil yakıt fiyatındaki artış (Burschel 1995).

Şekil 8'de, fosil yakıt fiyatlarının 1992-2034 yılları arasındaki dalgalanma seyri ve artış trendi görülmektedir. Yıllar itibariyle 1992 yılında düşük olan fosil yakıt fiyatları 2006 ve 2020 yılları arasında büyük bir artış gösterirken, bu artışın 2034 yılına gelindiğinde bundan çok daha fazla olacağ tahmin edilmektedir. Buna karşılık, daha doğal ve yeşil enerji olarak tabir edilen odun kaynaklı enerji fiyatları daha düşük ve istikrarlı olarak izlenmektedir.

Almanya Yenilenebilir Enerji Ajansı'nın 2011 yılında yapmış olduğu araştırmaya göre, küresel ısınma ve iklim değişikliğinin önüne geçilebilmesinin ancak doğal enerji ile mümkün olduğu dile getirilmiştir. Fosil yakıtlardan 
enerji üretiminde açığa çıkan $\mathrm{CO} 2$ miktarı en yüksek oranda iken, bunu güneş enerjisinin takip ettiği görülmektedir. En fazla çevre dostu enerji türünün ise odun ve odun türevi ürünler olduğu, Şekil 9'da görülmektedir. Odun ve odun türevli enerjinin kullanımı iklim değişikliğine uyum konusunda büyük oranda katkı sağlamaktadır.

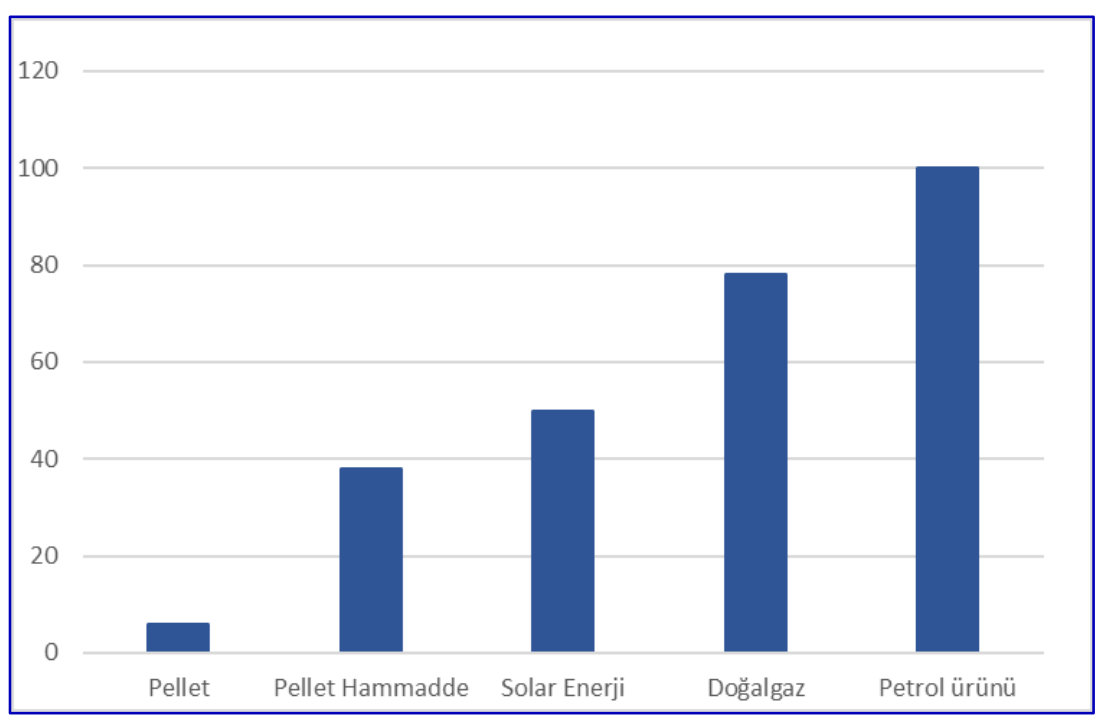

Şekil 9. Enerji üretiminde kullanılan kaynakların sera gazı emisyonları (Vogt vd. 2011).

Odun kullanımının temiz kalkınma mekanizmaları kapsamında çevresel katkısı üzerine 2013 yılında yapılan araştırmada, Almanya'nın 2020 hedeflerinde yenilenebilir enerjinin payı en az \%35 olarak belirlenirken, 1S1 talebinin en az \%14'ünün ise yenilenebilir kaynaklardan karşılanması öngörülmektedir. Yine, bu konuda Almanya için 2025 hedefinin \%40-45 arası ve 2035 yılı hedefinin ise \%55-60 arasında olduğu açıklanmıştır (Rüter, 2013). Türkiye Elektrik İdaresi Anonim Şirketi (TEİAŞ) verilerine göre, Türkiye elektrik enerjisinin birincil enerji kaynaklarına göre dağılımı Şekil 10. 'da verilmektedir.

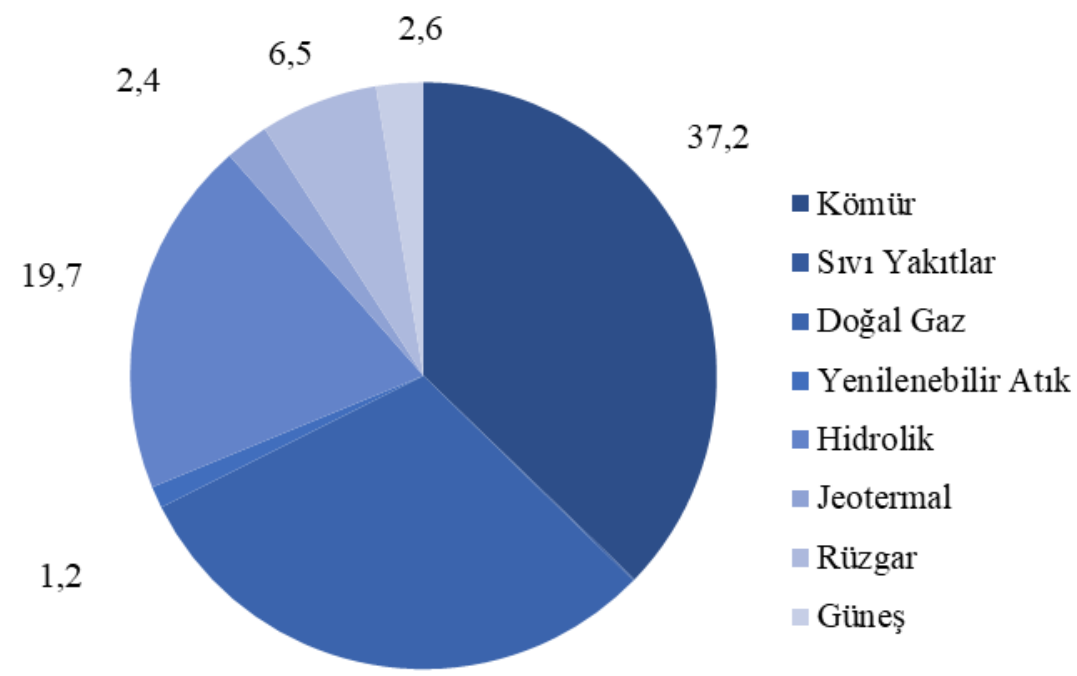

30,3

Şekil 10. Türkiye elektrik enerjisinin birincil enerji kaynaklarına göre dağılımı (URL8 2018).

Şekil 10'da verilen kurulu güç kaynakları incelendiğinde, en fazla elektrik üretiminin \%37,2 ile kömür olduğu görülmektedir. Bunu \%30,3 ile doğalgaz elektrik üretimi izlemektedir. Üçüncü sırada ise \%19,7 hidroelektrik üretimi yer almaktadır. Rüzgâr santrallerinden elde edilen enerji miktarı \%6,5 iken, diğer enerji kaynaklarının oranı ise toplamda $\% 6,2$ düzeyindedir. Türkiye geneline bakıldığında, odundan elde edilen enerji miktarının dikkate değer düzeyde olmadığı görülmektedir. 


\subsection{Türkiye'de Endüstriyel Odun Üretimi ve Kullanım Alanları}

TÜİK'in 2019 yılı verilerine göre toplam orman alanımız 22,3 milyon hektar olup; ülkemiz yüz ölçümünün \%28,6'sı ormanlarla kaplıdır. Bu varlığın \%52'si verimli ve \%48'ini bozuk ormanlar oluşturmaktadır. Ülkemizde orman ürünleri sanayinin gelişme durumu ve hammadde talebi göz önüne alındığında, mevcut üretim durumumuza göre oluşan arz açığını karşılamada endüstriyel plantasyonların önemi ortaya çıkmaktadır (URL7 2019)

Bu çerçevede OGM koordinasyonunda “Endüstriyel Ağaçlandırma Çalışmaları Eylem Planı (2013-2023)” ile endüstriyel ağaçlandırmalar için yapılacak ağaçlandırmalar belli bir plan ve program dâhilinde sürekliliğe kavuşturulmuştur. Söz konusu eylem planı ile ülke genelinde 1.450.000 dekarı kızılçam, 150.000 dekarı radiata çamı olmak üzere, okaliptüs, dişbudak gibi hızlı gelişen türlerle 1.650 .000 dekar alanda endüstriyel ağaçlandırma yapılması kararlaştırılmış olup, bugüne kadar 250.000 dekar alanda çalışma gerçekleştirilmiştir.

Sadece kamu olarak değil, gerçek ve tüzel kişilerin de odun hammaddesi üretimi maksadıyla yapacağı özel ağaçlandırma çalışmaları teşvik edilmiş, geçmiş dönemlerde verilen faizsiz kredi desteği ile 250 dekar alanda kızılçam, karaçam, sahil çamı gibi türlerle ağaçlandırma yapılması sağlanmıştır. Yine, bozuk ve açıklık vasıftaki orman arazilerinin doğrudan özel endüstriyel ağaçlandırma yapan tüzel kişiliklere tahsisinin önü açılmış ve bu kapsamda yapılacak ağaçlandırma çalışmalarına, yatırım giderleri tutarının \% 25'i oranında hibe desteği verilmesi sağlanmıştır. Bu çerçevede, bugüne kadar 20.000 dekar alanda özel endüstriyel ağaçlandırma uygulaması gerçekleştirilmiştir (OGM 2013).

Türkiye’deki endüstriyel odun üretimi miktarları ise ürün çeşitleri itibarıyla Tablo 7’de verilmiştir.

Tablo 7.Türkiye’de endüstriyel odun üretimi $\left(\mathrm{m}^{3}\right)$.

\begin{tabular}{llllll}
\hline Ürün adı & $\begin{array}{l}\mathbf{2 0 1 3} \\
(\mathbf{m} 3)\end{array}$ & $\begin{array}{l}\mathbf{2 0 1 4} \\
(\mathbf{m 3 )}\end{array}$ & $\begin{array}{l}\mathbf{2 0 1 5} \\
(\mathbf{m} 3)\end{array}$ & $\begin{array}{l}\mathbf{2 0 1 6} \\
(\mathbf{m} 3)\end{array}$ & $\begin{array}{l}\mathbf{2 0 1 7} \\
(\mathbf{m 3})\end{array}$ \\
\hline Lif-Yonga Odunu & 5.551 .397 & 6.608 .416 & 6.866 .356 & 7.201 .462 & 6.494 .372 \\
Tomruk & 4.629 .829 & 5.001 .861 & 5.904 .015 & 5.786 .107 & 5.474 .260 \\
Kâğıtlık Odun & 2.196 .434 & 1.966 .963 & 2.375 .172 & 2.486 .595 & 2.169 .059 \\
Sanayi Odunu & 701.688 & 728.972 & 764.010 & 835.157 & 752.253 \\
Maden Direği & 541.771 & 570.156 & 663.689 & 632.168 & 561.967 \\
Tel Direği & 32.641 & 37.527 & 54.257 & 57.574 & 60.610 \\
Sirık & 14.227 & 9.314 & 10.098 & 10.935 & 9.102 \\
Toplam & 13.667 .987 & 14.923 .209 & 16.637 .598 & 17.009 .998 & 15.521 .622 \\
\hline Kaynak: URL4
\end{tabular}

Kaynak: URL4 2018.

\section{Sonuç ve Öneriler}

Endüstriyel plantasyonların ABD, Brezilya ve Çin gibi ülkelerde ekonomik kalkınma ve büyüme parametreleri açısından önemli rol oynadığı görülmektedir. Brezilya için okaliptus dikimi ve endüstrisi vazgeçilmez bir ekonomik faktör haline gelmiştir. Bu ülkeleri, Rusya ve Japonya'nın izlediği görülmektedir. Küresel ölçekte ekonomik gelişmişlik düzeyi ile endüstriyel plantasyonların yaygınlaşması arasında bir paralellik olduğu görülmektedir. Önümüzdeki yıllarda, gelişmiş ülkelerdeki biyoenerjiye geçiş eğiliminden dolayı bu sektörün daha da genişleyip, ekonomik yönden ülkelerin kalkınmasına daha fazla katkı sağlayacağı tahmin edilmektedir.

Araştırmalar, enerji üretimi amaçlı kullanılan fosil yakıt fiyatlarının önümüzdeki dönemlerde Dünya genelinde daha da artacağını göstermektedir. Türkiye'nin de daha temiz ve ucuz enerji kaynağı olan biyolojik kökenli odun esaslı enerjiye yatırım yapması önerilmektedir. Böylece, doğal kaynaklarımızı koruyarak küresel iklim değişikliğinden en az düzeyde etkilenmek mümkün olabilecektir.

Orman alanı ve ağaç serveti açısından yeterli bir düzeyde bulunan Türkiye'de orman ürünleri ve özellikle de odun hammaddesi üretimi açısından arz açığı bulunmaktadır. Orman ve orman ürünleri dış ticareti bakımından negatif bir balans söz konusudur. Dolayısıyla odun ürünleri bakımından ortaya çıkan arz açığının kapatılmasının en önemli yollarından biri endüstriyel plantasyonlara ağırlık vererek uygun alanlarda yaygınlaşmasını sağlamaktır. Bu konuda araştırmaların ve saha denemelerinin gerçekleştirilerek ağaçlandırma yatırımlarına hız verilmesi gerektiği 
düşünülmektedir. Zira, Türkiye'nin fiziki coğrafya ve ekolojik şartları bakımından endüstriyel plantasyona uygun alanları bulunmaktadır. Dünyada bulunan tüm toprak tipleri hemen hemen Türkiye'de mevcut ve birbirinden çok farklı iklim tiplerine de sahipken, odun ve bazı orman ürünleri ithalatı azaltıp ihracatı artırmak sadece zaman ve bilimsel çalışmaya bağlı bulunmaktadır.

Diğer taraftan, endüstriyel plantasyonlara ilişkin yatırımların artırılması hem ülke ekonomisi hem de odun hammaddesi ihtiyacının karşılanması açısından önemli olmanın yanı sıra, doğal kaynakların ve bilhassa orman varlığının korunması açısından uygun görülmektedir. Ayrıca, bitki çeşitliliği bakımından oldukça zengin olan ülkemizde yerel türlerin endüstriyel plantasyon bakımından araştırılmasının gerekliliği üzerinde durulmalıdır. Orman ürünlerine olan talep artışına rağmen, doğal ormanların odun üretimi dişındaki fonksiyonel hizmetlerine olan kamuoyu talepleri, potansiyel ağaçlandırma sahalarının ve endüstriyel ağaçlandırmanın gelecekteki odun arz açığının kapatılmasında giderek daha da önemli olacağı değerlendirilmektedir. Ancak, bu konuda özel sektör ormancılık yatırımlarının teşvik ve mali destek mekanizmaları ile geliştirilmesine ilişkin yasal düzenlemelerin yeterli ve hazır olduğu söylenememektedir.

\section{Kaynaklar}

1. Bemmann, A., Pretzsch, J. and Schulte A., (2008). Baumplantagen weltweit-eine Übersicht. Schweiz Z Forstwes. 6: 124-132.

2. Burschel, P., (1995). Wald-Forstwirtschaft und globale ökologie. Forstwissenschaftliches Centralblatt vereinigt mit Tharandter forstliches Jahrbuch 114-1: 80-96.

3. FAO, (2011). State of Europe's forests 2011 .Europe Forest. Unece and FAO. Rome.

4. FAO, (2007). State of the world's forests 2007. Food and Agriculture Organisation. Rome.

5. Finnish Forest Industries Federation, (2007). Finnish Forest Industries Yearbook 2007. FFIF: Helsinki.

6. OGM, (2013). Endüstriyel Ağaçlandırma Çalışmaları Eylem Planı (2013-2023), Orman ve Su İşleri Bakanlığı, Orman Genel Müdürlüğü, Ankara.

7. Richter, M., and Böcker, R., (2001). Städtisches Vorkommen und Verbreitungstendenzen des Blauglockenbaumes (Paulownia tomentosa) in Südwestdeutschland. Mitt.Dtsch.Dendrol.Ges. 86: 125-132.

8. Bemmann, A., Pretzsch, J. and Schulte A., (2008). Baumplantagen weltweit-eine Übersicht. Schweiz Z Forstwes. 6: 124-132.

9. Burschel, P., (1995). Wald-Forstwirtschaft und globale ökologie. Forstwissenschaftliches Centralblatt vereinigt mit Tharandter forstliches Jahrbuch 114-1: 80-96.

10. FAO, (2011). State of Europe’s forests 2011 .Europe Forest. Unece and FAO. Rome.

11. FAO, (2007). State of the world's forests 2007. Food and Agriculture Organisation. Rome.

12. Finnish Forest Industries Federation, (2007). Finnish Forest Industries Yearbook 2007. FFIF: Helsinki.

13. Karakuş, $\quad$ C., $\quad$ (2018). $\quad$ Araştırma $\quad$ Yöntemleri. Erişim http://ckk.com.tr/ders/arastirmayon/00\%20Ara\%C5\%9Ft\%C4\%B1rma\%20Y\%C3\%B6ntemleri.pdf Erişim Tarihi: 20 Ağustos 2020.

14. OGM, (2013). Endüstriyel Ağaçlandırma Çalışmaları Eylem Planı (2013-2023), Orman ve Su İşleri Bakanlığı, Orman Genel Müdürlüğ̈̈, Ankara.

15. Richter, M., and Böcker, R., (2001). Städtisches Vorkommen und Verbreitungstendenzen des Blauglockenbaumes (Paulownia tomentosa) in Südwestdeutschland. Mitt.Dtsch.Dendrol.Ges. 86: 125-132.

16. Rüter, S., (2013). Der Umweltbeitrag der Holznutzung. Urbaner Holzbau—Chancen und Potenziale für die Stadt. DOM Publishers, Berlin, Germany.[The Environmental Contribution of Wood Utilization], 86-97.

17. Stimm, B., Stiegler, J., Genser, C., Wittkopf, S., and Mosandl, R., (2013). Paulownia-Hoffnungsträger aus Fernost? Eine schnellwachsende Baumart aus China in Bayern auf dem Prüfstand, LWF aktuell, 96: 1821.

18. URL-1 (2012). Erişim Adresi: https://blog.gruenesgeld.net/der-deutsche-wald-und-der-druck-derwirtschaftlichkeit. Erişim Tarihi: 17 Ağustos 2020, Messina, J. Grünes, G., (2012). Der deutsche Wald und der Druck der Wirtschaftlichkeit.

19. URL-2 (2013). Erişim Adresi: https://www.orsiad.com.tr/orman-urunlerinde-ithalat-ihracat-durumu.html Erişim Tarihi: 17 Ağustos 2020, Orman ürünlerinde ithalat ihracat durumu, TOBB Orman Ürünleri, Ankara.

20. URL-3 (2014). www.cabi.org/fc. Erişim Tarihi: 20 Temmuz 2020, CABI, (2014). Paulownia tomentosa. In: Forestry Compendium. Wallingford, UK: CABI International.

21. URL-4 (2018). Erişim Adresi: https://www.ogm.gov.tr/ekutuphane/Sayfalar/Istatistikler.aspx Erişim Tarihi: 17 Haziran 2020, OGM, (2018). Resmi İstatistikler. Endüstriyel odun üretimi.

22. URL-5 (2018). Erişim Adresi: https://www.unece.org/forests/fpm/onlinedata.html Erişim Tarihi: 12 Haziran 2020,_FAO/UNECE, (2018). Data and Statistics. Forest Resources.

23. URL-6 (2018). Erişim Adresi: http://www.intracen.org/itc/sectors/services/tradestatistics/, Erişim Tarihi: 22 Haziran 2020, ITC, 2018. International Trade Center. Trade Statistics. 
24. URL-7 (2019). Erişim Adresi: http://www.tuik.gov.tr/PreTablo.do?alt_id=1001, Erişim Tarihi: 25 Haziran 2020, TÜİK, (2019). Konularına göre istatistikler. Tarım, Bitkisel üretim istatistikleri. İstatistiksel tablolar ve dinamik sorgulama. Tarım ve Orman Alanları.

25. URL-8 (2018). Erişim Adresi: $\quad$ https://www.teias.gov.tr/sites/default/files/2018/kurulu_guc haziran_2018.pdf. Erişim Tarihi: 25 Haziran 2020, TEİAŞ, (2018). Türkiye kurulu elektrik enerjisi gücü.

26. Vogt, R., Fehrenbach, H., and Hennenberg, K., (2011). PROSA Technically dried wood chips/wood pellets. Development of procurement directives for a climate protection related eco-label; PROSA Technisch getrocknete Holzhackschnitzel/Holzpellets. Entwicklung der Vergabekriterien fuer ein klimaschutzbezogenes Umweltzeichen.

27. Weisgerber, H., and Weisgerber, E., (2004). Acacia dealbata. Enzyklopädie der Holzgewächse: Handbuch und Atlas der Dendrologie, 1-17.

28. World Bank, (2011). Word Development Report 2011: Conflict, Security, and Development, World Bank, Washington DC. 